\title{
Comparison of Real-Time PCR and Conventional PCR by Identifying Genomic DNA of Bovine and Porcine
}

\author{
Ahlam Inayatullah ${ }^{1}$, Annisa Fatmawati ${ }^{2}$, Emelda ${ }^{2}$, Muhammad Abdurrahman Munir ${ }^{2 *}$ \\ ${ }^{1}$ Faculty of Science and Technology, Universiti Sains Islam Malaysia, Bandar Baru Nilai, Nilai, Negeri Sembi- \\ lan, 71800, Malaysia \\ ${ }^{2}$ Department of Pharmacy, Faculty of Health Science, Universitas Alma Ata, Bantul, Daerah Istimewa Yogya- \\ karta, 55183, Indonesia \\ *Corresponding Author: muhammad@almaata.ac.id
}

\begin{tabular}{l}
\hline ARTICLE INFO \\
\hline Article History: \\
Received date: 16 June 2021 \\
Revised date: 25 August 2021 \\
Accepted date: 27 September 2021 \\
Available online at: November 2021
\end{tabular}

Keywords:

Bovine, Porcine, PCR, DNA.

\begin{abstract}
Bovine and porcine are poultry meat that is consumed worldwide, particularly in Southeast Asia. Both of them are prone to food counterfeit owing to several factors such as price, appetite and Halal status. Sensitive and selective analytical methods are required to control meat products distributed to markets. This paper studied the sensitivity between real-time and conventional PCR. Bovine and porcine were used as the sample to verify the sensitivity of the method. The result of the study found that the assays did not show a specific difference during DNA analysis of bovine and porcine. In conventional PCR, two pairs of DNA primers targeted cytochrome $b(C y t b)$ were analyzed, resulting in 120 and 131 amplicons, respectively. While qPCR was applied to analyze porcine and bovine DNA. The detection limit of qPCR after porcine and bovine analysis was 0.004 and $0.007 \mu \mathrm{g} / \mu \mathrm{L}$, respectively. Results demonstrated that the qPCR was reliable for verifying porcine and bovine DNA compared to conventional PCR. Furthermore, the study concluded that the developed assay could easily identify porcine and bovine tissue in food products in low resource areas.
\end{abstract}

(C) 2021 Jurnal Kimia Terapan Indonesia. This is an open access article under the CC BY-NC-SA license (https://creativecommons.org/licenses/ by-nc-sa/4.0/).

\section{INTRODUCTION}

Nowadays, analysis of food products is imperative to identify the quantity and quality of food, preventing food adulteration and promoting food safety. Meat species analysis becomes a persistent issue that must be handled for several reasons such as (a) the quantity of meat that is different compared on the product label, (b) substitute high-quality meats partially, even for some cases convert entirely with low-quality then put counterfeit label deliberately before distributed to markets, (c) the concentration of meat inside non - meat products and (d) to follow the regulation of certain country related to Halal food, where Islamic law stringently prohibits the consumption of specific meat products (e.g., porcine products) (Dolch et al. 2020; Zia et al. 2020; Kang et al. 2021). Those reasons should be considered to satisfy and protect consumers. There are several approaches to detect meat species in foods, such as genomics (Wang et al. 2019; Sultana et al. 2020), spectroscopy (Sankar et al. 2020; Cebi et al. 2019), chromatography (Ekasary et al. 2018; Sha et al. 2018), morphology (Labrooy et al. 2018; Zhang et al. 2019), immunochemical (Tukiran et al. 2016) and proteomics (Chis \& Vodnar 2019; Wang et al. 2019). The genomic 
method with the PCR technique has been used by Li et al. (2021) to detect the species content in the product accurately. Furthermore, living organisms have their own DNA' molecules that very unique for each organism (Williams et al. 2020; Zulch et al. 2020). PCR technique is strongly selective and sensitive by multiplying nucleotide sequence-specific nucleotides exponentially in vitro (Toohey - Kurth et al. 2020).

The concept of PCR requires the specific DNA sequence parts to be multiplied before the multiplication process can be done. The sequence is imperative to provide a primer where the short oligonucleotide sequence initiates the DNA synthesis in a polymerase chain reaction ( $\mathrm{Li}$ et al. 2020). Furthermore, the reaction is followed by a heating machine that provides thermal conditions for amplification purposes (Mancini et al. 2020). The process inside the PCR machine is divided into three steps such as denaturation (double-stranded DNA separation), annealing and extension (primer elongation) (Liu et al. 2020).

The PCR method generally applied nowadays is real-time PCR or known as quantitative polymerase chain reaction (qPCR). It has advantages compared to conventional PCR (cPCR) that can continuously record the products accumulation during the cycle where $\mathrm{cPCR}$ still relies on agarose gel electrophoresis to determine the amplicons (Dorlass et al. 2020). The quantity of qPCR is calculated by applying the threshold cycle $(\mathrm{Ct})$ based on fluorescent intensity induced by noise (background fluorescence). Noise causes the attachment of DNA solution isolates along with PCR reagents in the tube wall (Karami et al. 2020). Several advantages of qPCR have been studied and published by researchers (Yang et al. 2020; Cellier et al. 2020; Guo \& Pooler 2020; Ahmed et al. 2020; Kim et al. 2020; Farhan et al. 2020; Zheng et al. 2020) owing to the high precision and accuracy during the detection in each cycle (exponential phase) compared to cPCR that determines in the final phase of amplification (the plateau phase) due to the accuracy is lower than qPCR (Karimi et al. 2020). Ferreira et al. (2018) studied the assessment of conventional PCR and real-time PCR for screening Streptococcus agalactiae in pregnant women, and the result shown among the 130 clinical specimens used in the study. In comparison, 23 (17.7\%) of the clinical specimens tested positive for GBS colonization with conventional PCR, and 38 (29.2\%) tested positive with qPCR. The study concluded that the $\mathrm{qPCR}$ technique had a better performance in identifying positive SGB clinical specimens than conventional PCR.

The basic of PCR technique is the selection of primer to be used. The specific primer will be attached to the region-specific to the DNA template and amplified into a new strand. A precise primer design is required to produce specific primers that match the target amplification. To detect porcine and bovine DNA, one of the genes that can be used as a specific marker is the Cytochrome b gene (cyt b). Cytochrome b (mt Cytb) gene has been proved as an efficient tool with high power of discrimination for species identification and characterization in both taxonomy and forensic science (Saif et al., 2012). It is also used in studies of molecular evolution (Prusak et al., 2004). The gene length is $1140 \mathrm{bp}$ and has some stable sequences used to suggest universal primers for typical PCR-based methods (Parson et al., 2000).

Method validation is the practical process of determining the suitability of a method for providing analytical data that is fit for the intended purpose. For any method to produce meaningful and reliable data, some performances checks should be made before the method is applied to a real sample (Ali et al., 2012). There are many performances characteristics that can potentially be investigated for a particular method, some of which are used in this study.

Specificity is the ability to measure only certain substances carefully and thoroughly with the other components present in the sample matrix (Brown, 2005). The component of the specificity test in this study is the oligonucleotide primer. The nucleotide sequence is specified using NCBI Blast software to confirm the species origin of the sequence of oligonucleotide primer.

The study determined the detection limit (DL) of each PCR method under their optimal conditions using five total series of genomic DNA. Practically there are several ways of determining the detection limit of a method. The analyte is typically diluted serially in qualitative 
analysis until it can no longer be detected reliably using the method. The efficiency is additional information to show how accurate and reliable real-time PCR compare to conventional PCR. The study compares both assays using a descriptive approach. The different techniques of both assays make it is impossible to compare quantitatively. This study aimed to introduce a suitable and sensitive technique between real-time and conventional PCR.

\section{EXPERIMENTAL SECTION}

\subsection{Materials and Method}

\subsubsection{Sample Preparation}

Two different genomic DNAs animal species samples from porcine and bovine sources were obtained from Eurofins, respectively (Table 1). Porcine and bovine DNA were prepared by dissolving the control DNAs of porcine and bovine in distilled water with series of concentrations $10^{-1}-10^{-5} \mathrm{ng} / \mu 1$.

Table 1. General description of control DNAs employed in this study

\begin{tabular}{|c|c|c|c|}
\hline $\begin{array}{l}\text { Genomic } \\
\text { Type }\end{array}$ & $\begin{array}{l}\text { Company } \\
\text { Name }\end{array}$ & Batch no. & $\begin{array}{l}\text { Con- } \\
\text { centra- } \\
\text { tion }\end{array}$ \\
\hline $\begin{array}{l}\text { Genomic } \\
\text { DNA of } \\
\text { Cattle } \\
\text { (Bos } \\
\text { taurus) }\end{array}$ & Eurofins & 5222581306 & $\begin{array}{l}150 \mathrm{~mL} \\
{[\mathrm{ng} / \mu \mathrm{l}]}\end{array}$ \\
\hline $\begin{array}{l}\text { Genomic } \\
\text { DNA of } \\
\text { Pig (Sus } \\
\text { scrofa } \\
\text { domes- } \\
\text { tica) }\end{array}$ & Eurofins & 5212581501 & $\begin{array}{l}150 \mathrm{~mL} \\
{[1 \mathrm{ng} /} \\
\mu \mathrm{l}]\end{array}$ \\
\hline
\end{tabular}

\subsubsection{Primer Design}

A DNA sequence of the mitochondrial genome was obtained from Tanabe et al. (2007). Regions with high similarity were chosen for primer binding sites in the area coding for the Cytochrome $b$ gene. The theoretical specificity of all primers was checked with the Primer-BLAST software (Basic Local Alignment Search Tool, NCBI). The primers used for species-specific amplification of porcine genomic DNA were 5' -CTT GCA
AAT CCT AAC AGG CCT G -3' (forward) and 5' -CGT TTG CAT GTA GAT AGC GAA TAA C-3' (reverse). The primers used for species-specific amplification of bovine genomic DNA were 5' -CCC GAT TCT TCG CTT TCC AT-3' (forward) and 5' -CTA CGT CTG AGG AAA TTC CTG TTG-3' (reverse). Custom synthetic oligonucleotide primers were obtained from IDT. The sizes of the expected porcine and bovine amplicons were small (131 bp and $120 \mathrm{bp}$, respectively), which were essential given the extent of DNA degradation possible in highly processed products.

\subsubsection{Real-Time PCR Assay}

Genomic DNA of cattle and pig were diluted and subjected to the SYBR green-based PCR. The reaction was carried out using the SsoAdvanced universal SYBR Green supermix kit (BioRad, USA) $10.4 \mu \mathrm{L}$, with the $10 \mu \mathrm{M}$ and $0.4 \mu \mathrm{L}$ of reverse and forward primer, and a DNA concentration adjusted to $2 \mu \mathrm{L}$. The supermix kit is a reagent to help the PCR assay to send a signal and stabilize the PCR assay. The kit contains dNTPs, $\mathrm{MgCl}_{2}$, SYBR green I dye, enhancers and stabilizers. Amplification was performed in the StepOnePlus System (Applied Biosystems, USA) under the following conditions of temperature and cycling: an initial cycle at $95{ }^{\circ} \mathrm{C}$ for 10 minutes (pre denaturation stage); 40 cycles at 95 ${ }^{\circ} \mathrm{C}$ for 10 s (denaturation stage), and continued at $63{ }^{\circ} \mathrm{C}$ for $45 \mathrm{~s}$ (annealing and elongation stage). The stage was continued to measure melting temperature for 1 cycle at $95{ }^{\circ} \mathrm{C}$ in $15 \mathrm{~s}$ and then cooled at $60{ }^{\circ} \mathrm{C}$ for $30 \mathrm{~s}$. This stage collects the fluorescence signal at the end of each cycle. The results were analyzed using the cycle threshold $(\mathrm{Ct})$ and $\mathrm{Tm}$.

\subsubsection{Conventional PCR assay}

This study used the same reaction as described by real-time PCR assay. Amplification was performed in the T100 Thermal Cycler (BioRad, USA). The performance was begun at $95^{\circ} \mathrm{C}$ for 7 minutes and continued with the denaturation stage at a similar temperature for 30 seconds. The second stage was the annealing stage, where primer was designed to anneal the single-stranded 
DNA target. While for porcine primer, the annealing stage was at $63^{\circ} \mathrm{C}$ whereas the annealing stage for bovine primer was at $61^{\circ} \mathrm{C}$. The stage was repeated for 40 cycles. Furthermore, the elongation was the third step that must be occurred at temperature $72^{\circ} \mathrm{C}$ and proceeded to the last step at a similar temperature for 7 minutes. Afterward, the PCR products were determined using electrophoresis in $1 \%$ agarose gels in $1 \mathrm{x}$ TAE buffer followed by gel green staining and visualization under UV light transillumination. The $1 \mathrm{~kb}$ DNA ladder marker was applied to determine the size of all DNA fragments.

\subsubsection{Statistical Analysis}

The most effective means to measure assay performance is by constructing a standard curve from a serial dilution template (Hofmann et al., 1999). A type-I error $(\alpha)$ of $5 \%$ and equivalent 95\% coverage for genomic DNA was used for all analyses. Correlation between Ct-values against the log of the target concentration was calculated using Pearson's correlation coefficient and expressed as its associated $\mathrm{R}^{2}$ (which is the squared correlation, the percentage of variance explained or in common). Efficiency can be calculated according to the equation: $10^{(-1 / \text { slope })}-$ 1. The calculation was performed in Microsoft Excel 2016 (Redmond, USA).

\section{RESULTS AND DISCUSSION}

\subsection{Real-time PCR}

The diagnostic status of the sample was determined based on the obtained $\mathrm{Ct}$ value. The range of $\mathrm{Ct}$ values for SYBR Green dye in porcine samples was $18.14-31.94$. While the bovine sample was $19.84-34.46$. The $\mathrm{Ct}$ values range was not exceeding more than 40 , and it may be stated that the $\mathrm{Ct}$ values obtained from the two primers are acceptable (Table 2).

Five-fold dilution series of $10^{-1}-10^{-5}$ gave standard curves for detecting the genomic DNA of each bovine and porcine in real-time PCR. The one-step real-time PCR system's efficiency and $\mathrm{R}^{2}$ values were $97.4 \%$ and 0.962 for porcine, and $90.6 \%$ and 0.995 for bovine, respectively (Figure $1)$.
Table 2. Mean Ct Values Obtained with the Realtime PCR

\begin{tabular}{ccccc}
\hline $\begin{array}{c}\text { Con- } \\
\text { cen- } \\
\text { tration } \\
\text { (ng/ } \\
\mu \text { Ml) }\end{array}$ & \multicolumn{2}{c}{ Porcine Primer } & \multicolumn{2}{c}{ Bovine Primer } \\
\cline { 2 - 5 } & \pm SD & RSD & $\begin{array}{c}\text { Mean } \\
\pm \text { SD }\end{array}$ & $\begin{array}{c}\% \\
\text { RSD }\end{array}$ \\
\hline $10^{-1}$ & $18.14 \pm 0.79$ & 3.99 & $19.84 \pm 1.58$ & 8.69 \\
\hline $10^{-2}$ & $21.92 \pm 1.07$ & 4.60 & $23.22 \pm 2.13$ & 9.70 \\
\hline $10^{-3}$ & $24.77 \pm 1.31$ & 4.90 & $26.79 \pm 1.14$ & 4.60 \\
\hline $10^{-4}$ & $28.11 \pm 2.07$ & 7.12 & $29.02 \pm 0.37$ & 1.31 \\
\hline $10^{-5}$ & $31.94 \pm 0.66$ & 1.90 & $34.46 \pm 0.75$ & 2.36 \\
\hline
\end{tabular}

SD: standard deviation; RSD: relative standard deviation

The correlation between the $\mathrm{Ct}$ value and the log concentration of five-fold dilution using Pearson's analysis showed a negative correlation (Porcine: -3.386 and Bovine: -3.569) with a $\mathrm{p}$ value $<0.05$ (Figure 1), indicating the higher the concentration of DNA in the DNA sample, the lower the $\mathrm{Ct}$ value obtained. On the other hand, the lower the DNA concentration, the higher the $\mathrm{Ct}$ value.

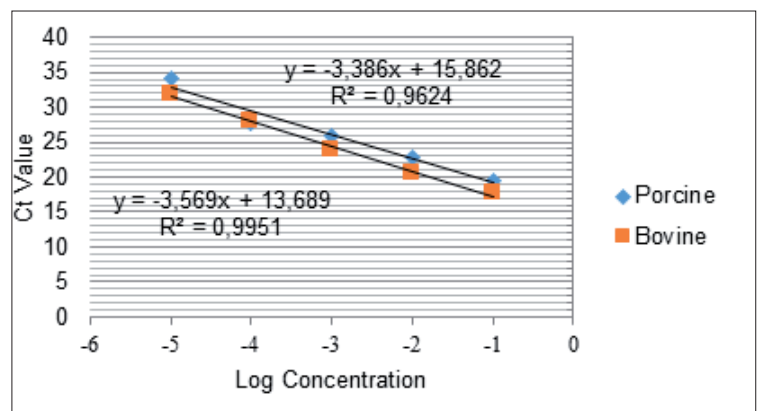

Figure 1. Standard Curves of 5-fold Dilutions of Porcine and Bovine DNA

The real-time quantitative PCR method proposed in this study allowed us to detect each DNA over a wide range. The amplification of each DNA species was clearly observed in a range between $0.1-0.00001 \mathrm{ng} / \mu \mathrm{l}$. In the case of 0.00001 of each DNA species, amplification was apparently detected. Hence, we concluded that the limit of detection of those porcine DNA and bovine DNA species were $10^{-5} \mathrm{ng} / \mu \mathrm{l}$ since it has shown an amplification curve for this concentration.

For the primer specificity test for bovine and porcine, both primers showed specific results which can be seen in Figure 2 for the porcine 


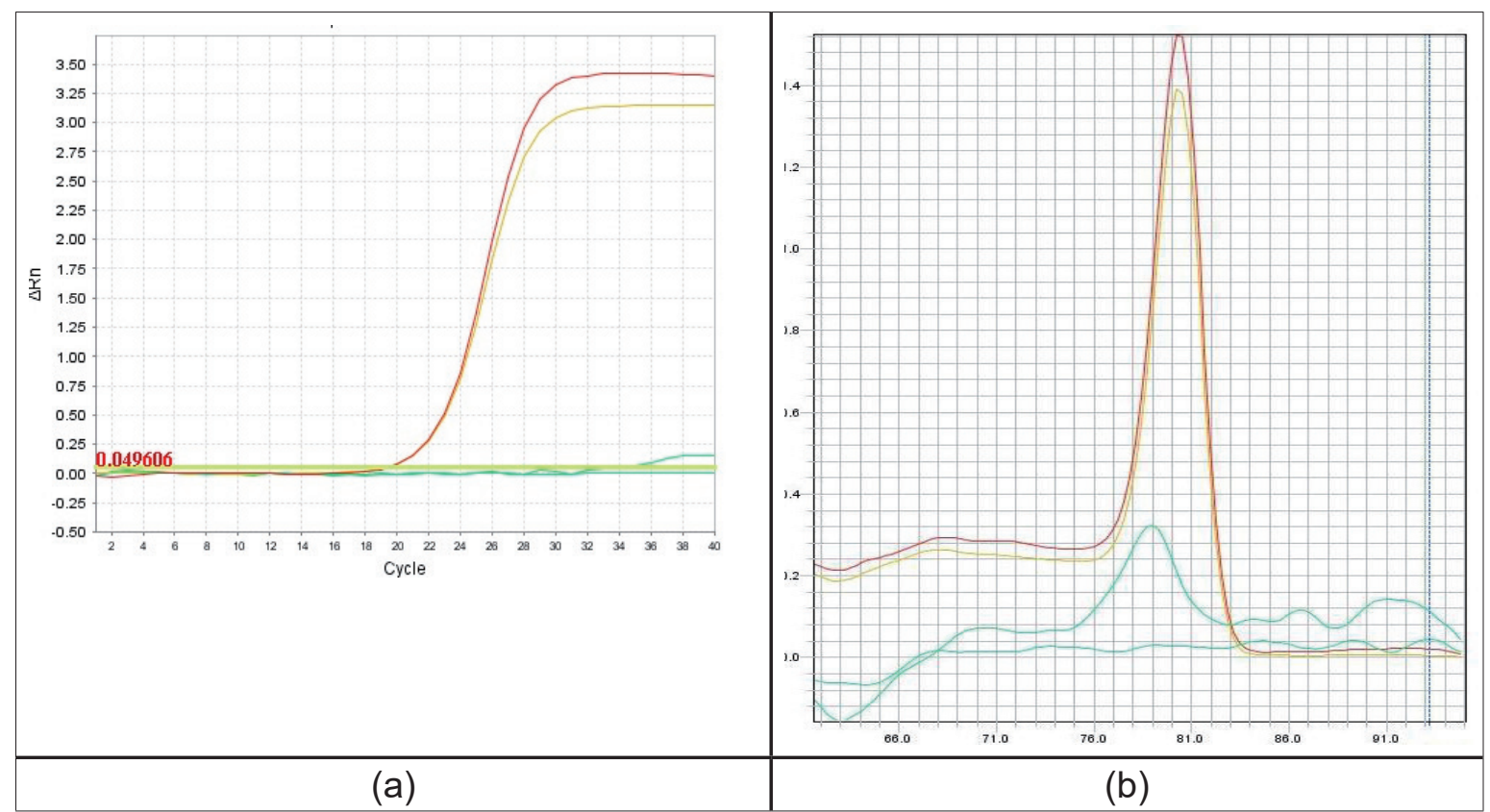

Figure 2. The amplification plot of Porcine DNA using qPCR (a) amplification plot and (b) Melting Curve

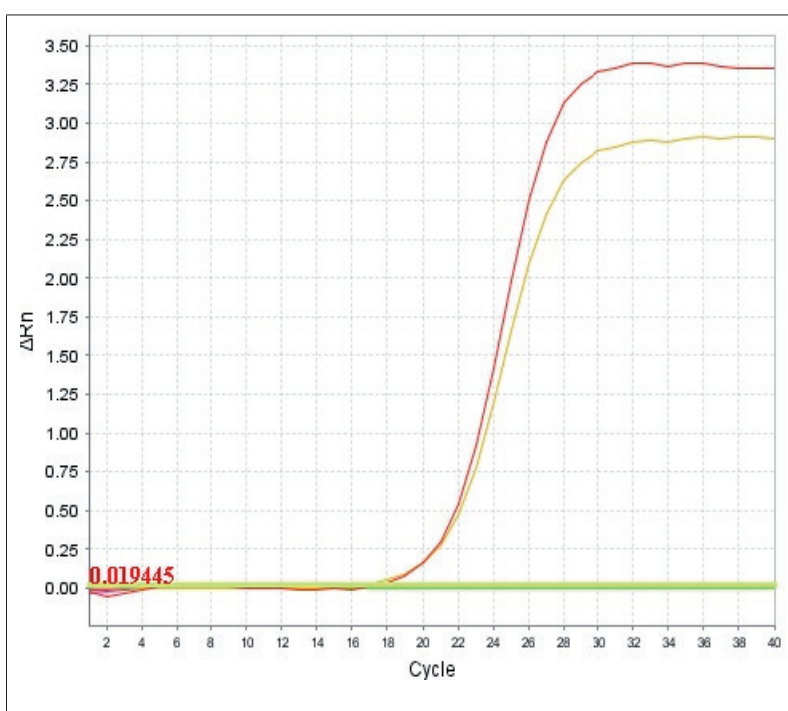

(a)

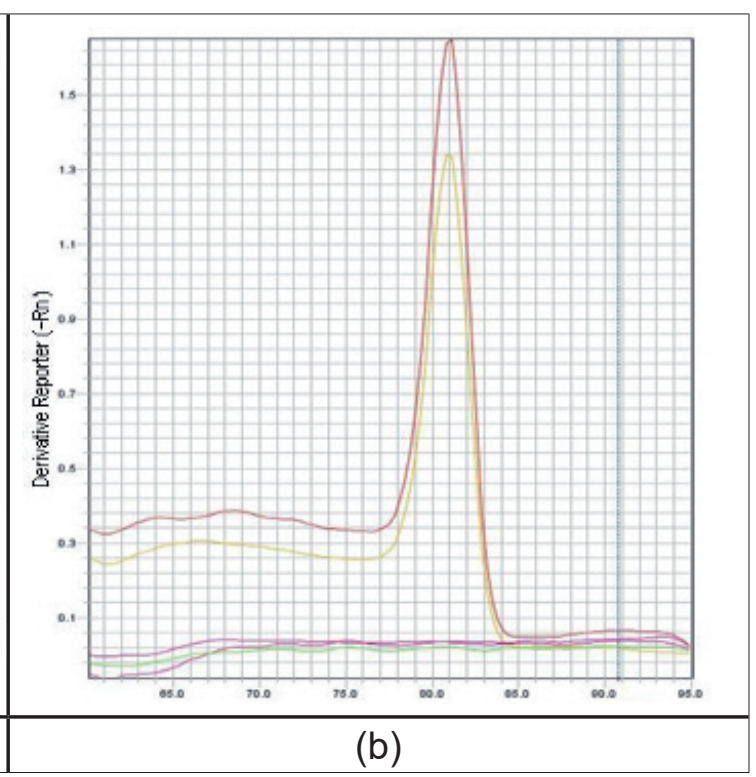

(b)

Figure 3. The amplification plot of Porcine DNA using qPCR (a) amplification plot and (b) Melting Curve

test and Figure 3 for the bovine test where the negative control sample did not experience an increase in the amplification curve. This shows that the SYBR Green method with bovine and pig primers can amplify their respective DNA identities specifically. The specificity of the amplification process using SYBR Green can be analyzed through Melting peaks. A specific amplification process will produce one type of peak with the same Tm value (Figure 2 and Figure 3 ). However, in porcine DNA testing, a Tm peak ap- peared, which was known to come from a negative control sample (bovine DNA) at $79^{\circ} \mathrm{C}$ that indicated that non-specific amplification products had been formed. The event is often referred to as mispriming or primer-dimer. Primer-dimer is the formation of a secondary structure caused by the annealing of similar primers or dissimilar primers, such as between forward primers and reverse primer complements. Meanwhile, mispriming is the attachment of primers outside the target DNA sequence (Ponchel, 2007). 

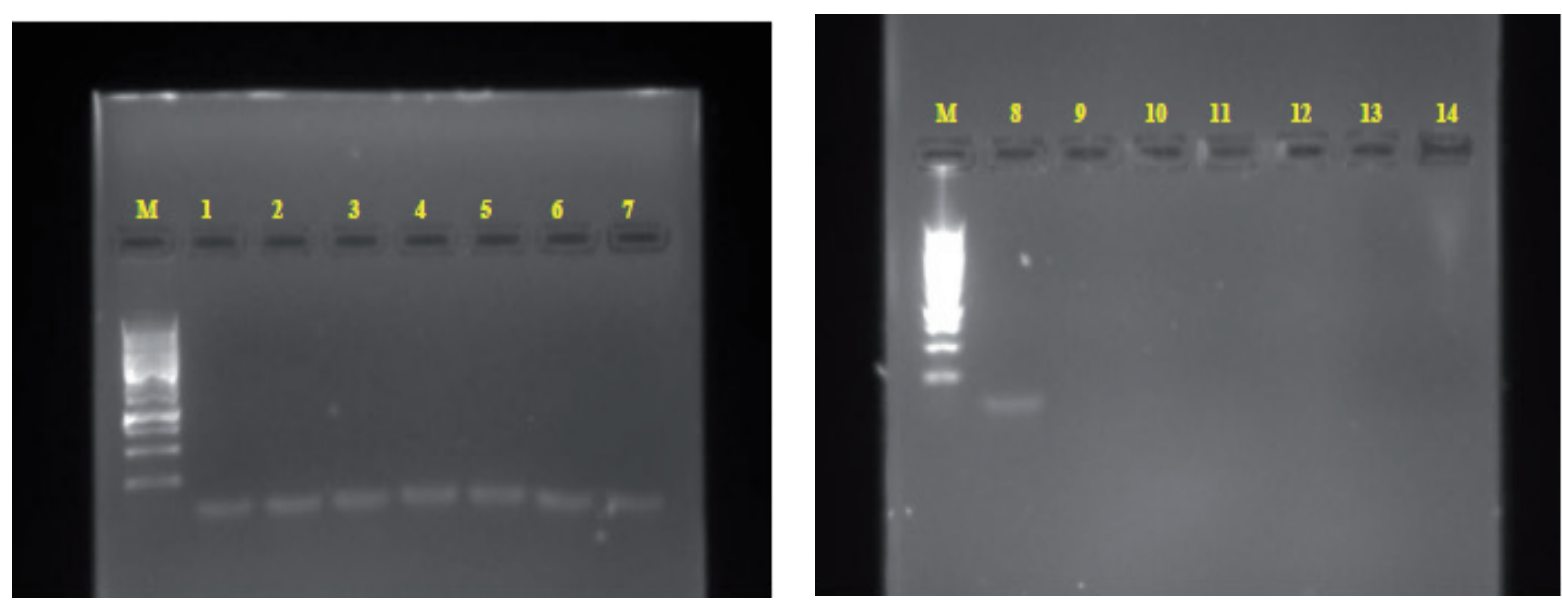

(a)
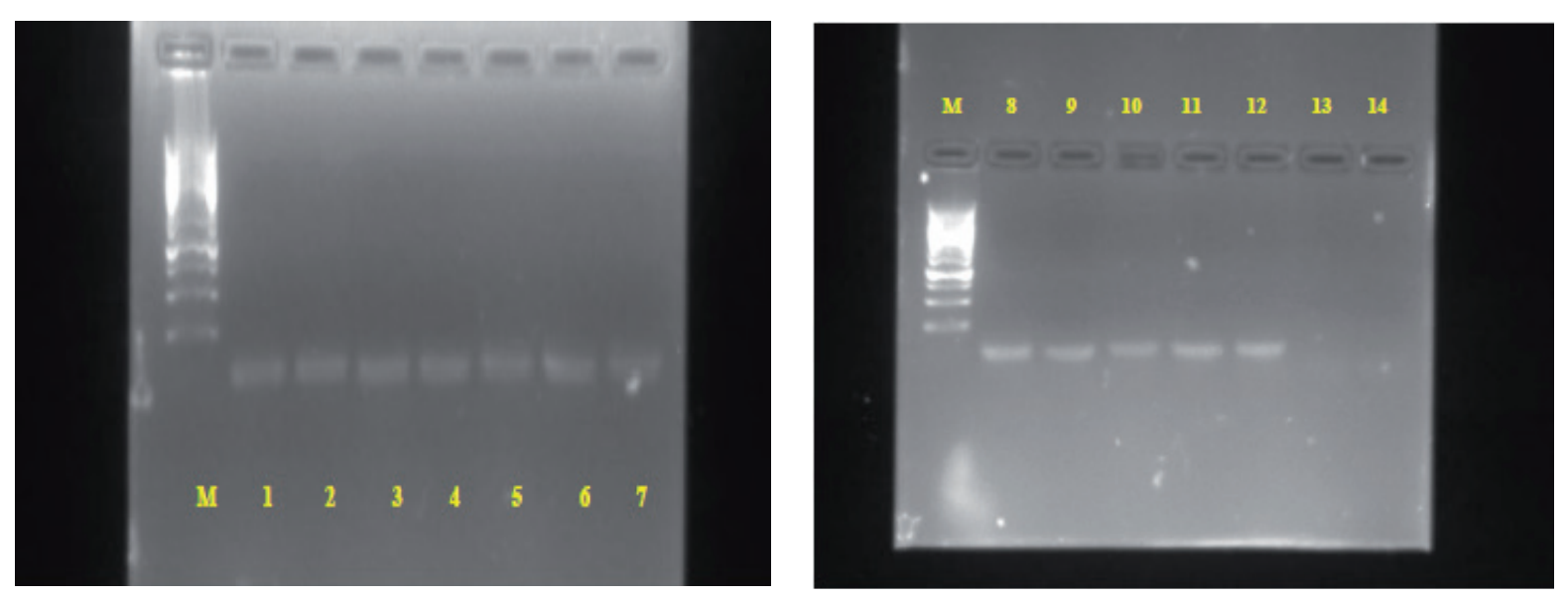

(b)

Figure 4. Visualization of conventional PCR of (a) bovine and (b) porcine. Gel analysis of the Conventional PCR products of 5-fold dilutions of bovine and porcine DNA to determine sensitivity and specificity. Lane M, AmpliSize 300-10,000 base pairs (bp) in $1 \mathrm{~Kb}$ increments. Lane 1-2: 0.1 ng/ $\mu \mathrm{L}$ : Lane 3-4: 0.01 ng/ $\mu \mathrm{L}$; Lane 5-6: 0.001 ng/ $\mu \mathrm{L}$; Lane 7-8: 0.0001 ng/ $\mu \mathrm{L}$; Lanes 9-10: 0.00001 ng/ $\mu \mathrm{L}$; Lane 11-13: negative control; Lanes 14: blank.

\subsection{Conventional PCR}

The results of DNA amplification with conventional PCR were described in gel documentation (Figure 4) and showed that the genomic bands in bovine and porcine DNA were clearly visible without smear. It can be concluded the DNA of cows and pigs has a high purity in low concentrations. Amplification was carried out simultaneously based on the specifications of the DNA being tested. The gel documentation was carried out twice for each DNA specification due to the insufficient number of holes in the gel comb in one process.

The specificity test of the primers using conventional PCR was shown in Figures 4a and 4b. From Figure $4 a$ it can be seen that specific primers for bovine can only amplify DNA sequences in bovine species and cannot amplify DNA sequences in pig species (Lane 11, 12 and 13). Different results were obtained for porcine primers where in Figure $4 \mathrm{~b}$ amplification occurs on lanes 11 and 12 (Bovine DNA). Improper annealing temperature can cause DNA not to be amplified or miss-priming during amplification. Thus, re-specification of pig primers was tested at annealing temperatures of 60,61 and $62^{\circ} \mathrm{C}$ and reduced the number of PCR cycles to 30 . However, the same result is seen on gel. The porcine primer can not specifically identify the porcine DNA. 
Although in sensitivity test porcine primers can detect porcine DNA in the concentration of $10^{-5} \mathrm{ng} / 20 \mu \mathrm{l}$ (Figure $4 \mathrm{~b}$ ), while bovine primers are only sensitive to the presence of bovine DNA to concentration of $10^{-4} \mathrm{ng} / 20 \mu 1$ (Figure 4a), The porcine primer designed by Tanabe (2007) was not effective and efficient to identify porcine DNA due to the lack of specific porcine detection.

\section{CONCLUSION}

According to the application of qPCR and cPCR, both showed satisfactory sensitivity during the analysis of porcine and bovine genomic DNA. Both assays can amplify to a sufficiently low concentration $\left(10^{-4}-10^{-5} \mathrm{ng} / 20 \mu \mathrm{l}\right)$. Unfortunately, the specific test of porcine primers in conventional PCR still requires optimization of annealing temperature. Optimization of annealing temperature is one of the important parameter criteria for the success of PCR. While each PCR method had its pros and cons, a final choice of the PCR method depends on the purpose of its application and the expected concentration of species product.

\section{CONFLICTS OF INTEREST}

The authors declare that they have no known competing financial interests or personal relationships that could have appeared to influence the work reported in this paper.

\section{ACKNOWLEDGEMENT}

The authors wish to thank the Faculty of Science Technology, Universiti Sains Islam Malaysia (USIM) for providing the facilities to finish this study.

\section{REFERENCES}

Brown, A.E. (2005). Laboratory Manual in General Microbiology: Microbiological Applications. United States of America: McGraw-Hill Company.

Cebi, N., Dogan, C. E., Mese, A. E., Ozdemir, D., Arıc1, M., Sagdi, O. (2019). A rapid ATR-FTIR spectroscopic method for classification of gelatin gummy candies in relation to the gelatin source. Food Chemistry, 277, 373 - 381. doi: 10.1016/j. foodchem.2018.10.125
Chis, L. M., Vodnar, D. C. (2019). Detection of the species of origin for pork, chicken and beef in meat food products by real-time PCR. Safety, 5, 83. doi.org/ 10.3390/safety5040083.

Dolch, K., Andree, S., Schwagele, F. (2020). Compariosn of real - time PCR quantification methods in the identification of poultry species in meat products. Foods, 9 (8), 1049. doi.org/10.3390/ foods 9081049

Dorlass, E.G., Monteiro, C.O., Viana, A.O., Soares, C. P., Machado, R. R. G., Oliveira, D. B. L. et al. (2020). Lower cost alternatives for molecular diagnosis of Covid - 19: conventional RT - PCR and SYBR green - based RT - qPCR. Brazilian Journal of Microbiology, 51, 1117-1123. doi. org/10.1007/s42770-020-00347-5

Ekasary, A., Harmita, Maggadani, B. P. (2018). Optimized high-performance liquid chromatographyfluorescence detection method for the measurement of glycine, proline, and hydroxyproline concentrations in porcine gelatin. International Journal of Applied Pharmaceutics, 10, 325-360. doi.org/10.22159/ijap.2018.v10s1.72

Ferreira MB, de-Paris F, Paiva RM, Nunes LS. (2018). Assessment of conventional PCR and real-time PCR compared to the gold standard method for screening Streptococcus agalactiae in pregnant women. Brazilian Journal Infection Disease, 22(6), 449-454. doi: 10.1016/j.bjid.2018.09.005

Hofmann, K., K Fischer, E Mueller and W Babel. (1999). ELISA Test for Cooked Meat Species Identification on Gelatin and Gelatin Products. Food/Nahrung Journal, 43, 406-409.

Kang, S. J., Jang, C. S., Son, J. M., Hong, K. W. (2021). Comparison of seven commercial TaqMan master mixes and two real - time PCR platforms regarding the rapid detection of porcine DNA. Food Science of Animal Resources, 41 (1): 85 - 94. doi.org/10.5851/kosfa.2020.e80

Karami, A., Hasani, M., Jalilian, F. A., Ezati, R. (2020). Conventional PCR assisted single - component assembly of spherical nucleic acids for simple colorimetric detection of SARS - CoV - 2. Sensors and Actuators B: Chemical, 328, 128971. doi.org/10.1016/j.snb.2020.128971

Karimi, K., Arzanlou, M., Pertot, I. (2020). Development of novel species - specific primers for the specific identification of Colleotrichum nymphaeae based on conventional PCR and LAMP techniques. European Journal of Plant Pathology, 156, 463 - 475. doi.org/10.1007/ s10658-019-01895-9 
Kim, W. J., Yang, S., Choi, G., Park, I., Noh, P., Kim, M. J., Moon, B. C. (2020). Accurate and rapid identification of Longan Arillus and Litchi Semen by a Multiplex PCR Assay. Plants, 9 (8): 948. doi: 10.3390/plants9080948

Labrooy, C., Abdullah, T. L., Stanslas, J. (2018). Morphological and molecular datasets for Kaempferia species. Data in Brief, 21, 1678-1685. doi. org/10.1016/j. dib.2018.10.097

Li, F., Ye, Q., Chen, M., Shang, Y., Zhang, J., Ding, Y., Xue, L., Wu, S., Wang, J., Pang, R., Lei, T., Zeng, H., Wu, Q. (2021). Real - time PCR identification of Listeria monocytogenes serotype 4c using primers for novel target genes obtained by comparative genomic analysis. $L W T-$ Food Science and Technology. 138, 11077. doi. org/10.1016/j.lwt.2020.110774

Li, J., Wei, Y., Li, J., Liu, R., Xu, S., Xiong, S., Guo, Y., Qiao, X., Wang, S. (2021). A novel duplex SYBR Green real - time PCR with melting curve analysis method for beef adulteration detection. Food Chemistry, 338, 127932. doi.org/10.1016/j. foodchem.2020. 127932

Li, Y. D., Yu, Z. D., Bai, C. X., Zhang, D., Sun, P., Peng, M. L., Liu, H., Wang, J., Wang, Y. (2021). Development of a SYBR Green I real - time PCR assay for detection of novel porcine parvovirus 7. Polish Journal of Veterinary Sciences, 24 (1), 43 - 49. DOI. 10.24425/pjvs.2021.136791

Liu, X., Feng, J., Zhang, Q., Guo, D., Zhang, L., Suo, T., Hu, W., Guo, M., Wang, X., Huang, Z., Xiong, Y., Chen, G., Chen, Y., Lan, K. (2020). Analytical comparisons of SARS-COV-2 detection by qRT-PCR and ddPCR with multiple primer/ probe sets. Emerging Microbes \& Infections, 9 (1), 1175 - 1179. DOI: 10.1080/22221751.202 0.1772679

Parson, W.; Pegoraro, K.; Niederstatter, H.; Foger, M.; Steinlechner, M. (2000). Species identification by means of the cytochrome $\mathrm{b}$ gene. International Journal of Legal Medicine, 114(1-2), 23-28. DOI:10.1007/s004140000134

Ponchel F, Toomes C, Bransfield K. (2003). Real-time PCR based on SYBR-Green I fluorescence: an alternative to the TaqMan assay for a relative quantification of gene rearrangements, gene amplifications and micro gene deletions. $B M C$ Biotechnol, 3, 18. doi:10.1186/1472-6750-3-18

Prusak, B, Grzybowski, G, Zięba, G. (2004). Taxonomic position of Bison bison (Linnaeus, 1758) and Bison bonasus (Linnaeus, 1758) based on analysis of cytb gene. Animal Science Paper Report, 22(1), 27-35.
Saif R, Babar ME, Awan AR, Nadeem A, Hashmi AS, Hussain T. (2012). DNA fingerprinting of Pakistani buffalo breeds (Nili-Ravi, Kundi) using microsatellite and cytochrome $\mathrm{b}$ gene markers. Molecular Biology Report, 39(2), 851-6. doi: 10.1007/s11033-011-0808-0.

Sankar, S., Yamaguchi, M., Kawabata, S., Ponnuraj, K. (2020). Streptococcus pneumonia surface adhesion PfbA exhibits host specificity by binding to human serum albumin but not bovine, rabbit and porcine serum albumins. The Protein Journal, 39, 1 - 9. doi.org/10.1007/s10930-019-09875-y

Sha, S. P., Anupama, A., Pradhan, P., Prasad, G. S., and Tamang, J. P. (2016). Identification of yeasts by polymerase-chain-reaction-mediated denaturing gradient gel electrophoresis in marcha, an ethnic amylolytic starter of India. Journal Ethnology Foods 3, 292-296. doi: 10.1016/J. JEF.2016.11.009

Sultana, S., Hossain, M. A. M., Azlan, A., Johan, M. R., Chowdhury, Z. Z., Ali, M. E. (2020). TaqMan probe based multiplex quantitative PCR assay for determination of bovine, porcine and fish DNA in gelatin admixture, food products and dietary supplements. Food Chemistry, 325, 126756. doi. org/10.1016/j.foodchem.2020.126756

Tanabe, S., M Hase, T Yano, M Sato, T Fujimura and H Akiyama. (2007). Real-Time Quantitative PCR Detection Method for Pork, Chicken, Beef, Mutton, and Horseflesh in Foods. Journal of Bioscience Biotechnology Biochemistry, 71, 5-3131.

Toohey-Kurth, K. L., Mulrooney, D. M., Hinkley, S., Lea Killian, M., Pedersen, J. C., Bounpheng, M. A., Pogranichniy, R., Bolin, S., Maes, R., Tallmadge, R. L., Goodman, L. B., Crossley, B. M. (2020). Journal of Veterinary diagnostic investigation, 32 (6), 815 - 825. doi: 10.1177/1040638720962076

Tukiran, N. A., Ismail, A., Mustafa, S., Hamid, M. (2016). Development of antipeptide enzyme linked immunosorbent assay for determination of gelatin in confectionery products. International Journal of Food Science \& Technology, 51, 54 - 60. doi.org/10.1111/ijfs. 12971

Wang, W., Liu, J., Zhang, Q., Zhou, X., Liu, B. (2019). Multiplex PCR assay for identification and quantification of bovine and equine in minced meats using novel specific nuclear DNA sequences. Food Control, 105, 29-37. doi.org/10.1016/ j.foodcont.2019.05.016 
Williams, M. M., Waller, J. L., Aneke, J. S., Weigand, M. R., Diaz, M. H., Bowden, K. E., Simon, A. K., Peng, Y., Xiaolo, L., Cassiday, P. K., Winchell, J., Tondella, M. L. (2020). Detection and characterization of diphtheria toxin gene - bearing Corynebacterium species through a new real - time PCR assay. Journal of Clinical Microbiology, 58 (10). DOI: 10.1128/ jcm.00639-20

Zhang, S., Mound, L. A., Feng, J. (2019). Phylogenetic relationships among Scirtothrips species and related genera (Thysanoptera, Thripidae) based on morphology. Zoologischer Anzeiger, 280, 1-13. doi.org/10.1016/j.jcz.2019.02.004.
Zia, Q., Alawani, M., Mokhtar, N. F. K., Nhari, R. M. H. R., Hanish, I. (2020). Current analytical methods for porcine identification in meat and meat products. Food Chemistry, 32, 126664. doi. org/10.1016/j.foodchem.2020.126664

Zulch, M. F., Pilotte, N., Grant, J. R., Minetti, C., Reimer, L. J., Williams, S. A. (2020). Selection and exploitation of prevalent, tandemly repeated genomic targets for improved real-time PCR-based detection of Wuchereria bancrofti and Plasmodium falciparum in mosquitoes. PLoS ONE, 15 (5): e232325. doi.org/10.1371/ journal.pone. 0232325 